\title{
Glutamate Receptors in the Rod Pathway of the Mammalian Retina
}

\author{
Krishna K. Ghosh, Silke Haverkamp, and Heinz Wässle \\ Max-Planck-Institut für Hirnforschung, Neuroanatomie, D-60528 Frankfurt, Germany
}

Rod bipolar $(\mathrm{RB})$ cells of the mammalian retina release glutamate in a graded, light-dependent fashion from 20 to 40 ribbon synapses (dyads). At the dyads, two classes of amacrine cells, the $\mathrm{Al}$ and All cells, are the postsynaptic partners. We examined the glutamate receptors (GluRs) that are expressed by $\mathrm{Al}$ and All cells using immunocytochemistry with specific antibodies against GluR subunits. Sections of macaque monkey and rabbit retina were examined by confocal microscopy. All amacrine cells were selectively labeled for calretinin, and Al cells in rabbits were labeled for 5-HT uptake. Thus, double- and triplelabeling for these markers and GluR subunits was possible. Electron microscopy using postembedding immunocytochemistry and double-labeling was applied to show the synaptic expression of GluRs. We also studied the synaptic localization of the two postsynaptic density proteins PSD-95 and glutamate receptor-interacting protein (GRIP). We found that All amacrine cells express the AMPA receptor subunits GluR2/3 and GluR4 at the RB cell dyads, and they are clustered together with PSD-95. In contrast, Al amacrine cells express the $\delta 1 / 2$ subunits that appear to be associated with kainate receptor subunits and to be clustered together with GRIP. The RB cell dyad is therefore a synapse that initiates two functionally and molecularly distinct pathways: a "through conducting" pathway based on AMPA receptors and a modulatory pathway mediated by a combination of $\delta 1 / 2$ subunits and kainate receptors.

Key words: AMPA receptors; $\delta$ subunits; kainate receptors; GRIP; PSD-95; monkey retina; rabbit retina; Al amacrine cells; All amacrine cells; rod bipolar dyad
In the scotopic pathway of the mammalian retina, rods are connected to rod bipolar (RB) cells. These do not synapse directly onto ganglion cells in the inner plexiform layer (IPL); instead, their output synapses (dyads) involve two classes of amacrine cells, generally named AI and AII cells (Kolb and Famiglietti, 1974; Famiglietti and Kolb, 1975). AII amacrine cells are a single type that makes glycinergic inhibitory synapses with off-cone bipolar cells (Sassoè-Pognetto et al., 1994; Grünert and Wässle, 1996) and contacts on-cone bipolar cells via large gap junctions (Mills and Massey, 2000; Feigenspan et al., 2001). In this way they produce signals of opposite polarity in on- and off-ganglion cells. AI cells are a mixed group of GABAergic amacrine cells that often provide a reciprocal synapse back onto the RB cell axon terminal. This summary of the rod synaptic pathway appears to be a constant constituent of mammalian retinal organization, despite alternative pathways described more recently (Soucy et al., 1998; Hack et al., 1999).

RB cells are depolarized by a light stimulus that is projected into their receptive field center (Dacheux and Raviola, 1986; Euler et al., 1996; Berntson and Taylor, 2000; Euler and Masland, 2000). Glutamate, their transmitter, is continuously released in a light-dependent manner at their axon terminals in the IPL (von Gersdorff et al., 1996; Tachibana, 1999). The actual release sites are the active zones at the ribbons (von Gersdorff, 2001). In the rabbit retina, up to 40 ribbons were found in $\mathrm{RB}$ terminals (Strettoi et al., 1992), whereas in the macaque monkey retina,

Received July 10, 2001; revised Aug. 13, 2001; accepted Aug. 17, 2001.

This work was supported by the Deutsche Forschungsgemeinschaft (SFB 269/B4) and by a Fellowship of the A. V. Humboldt Foundation to K.K.G. We are grateful to Dr. B. Lee and Dr. P. Martin for providing monkey eyes. We thank M. Dumbsky, W. Hofer, and G. S. Nam for excellent technical assistance; Dr. F. Priesnitz for his help with confocal microscopy; and I. Odenthal for typing this manuscript.

Correspondence should be addressed to Dr. Heinz Wässle, Max-Planck-Institut für Hirnforschung, Abteilung Neuroanatomie, Deutschordenstrasse 46, D-60528 Frankfurt/Main, Germany. E-mail: Waessle@mpih-frankfurt.mpg.de.

Copyright (C) 2001 Society for Neuroscience $0270-6474 / 01 / 218636-12 \$ 15.00 / 0$
20 ribbons were observed (Grünert and Martin, 1991). Hence, between 40 and 80 postsynaptic contacts are expected at individual RB axon terminals. At these contacts, aggregates of glutamate receptors (GluRs) and postsynaptic density proteins have been demonstrated (Brandstätter et al., 1998; Koulen et al., 1998a,b; Qin and Pourcho, 1999a,b, 2000, 2001). However, a detailed study of the GluRs expressed by the AI and AII amacrine cells at the $\mathrm{RB}$ cell dyad is still missing.

Ionotropic GluRs have been subdivided into three major groups: AMPA, kainate, and NMDA receptors. Our laboratory has previously shown that the NMDA receptor subunits NR1, NR2A, and NR2B are absent from RB cell dyads (Fletcher et al., 2000); therefore, they will not be dealt with here. Molecular cloning has shown that AMPA receptors are complexes of the subunits GluR1, GluR2, GluR3, or GluR4. Kainate (KA) receptors are composed of the subunits GluR5, GluR6, GluR7, KA-1, or KA-2. In addition, the orphan receptor subunits $\delta 1$ and $\delta 2$ are associated with these GluRs (Hollmann and Heinemann, 1994; Ozawa et al., 1998; Dingledine et al., 1999).

In the present study, we first focused on the macaque monkey retina and studied the localization of GluRs with immunocytochemical markers using both light and electron microscopy. RB cells were labeled with antibodies against protein kinase C (PKC) (Grünert and Martin, 1991), and AII cells were labeled with antibodies against calretinin (Wässle et al., 1995; Mills and Massey, 1999). Different GluR subunits and synapse-associated proteins could be localized to the RB cell dyads. Their precise position at the dyad was studied by labeling the RB cell ribbons with antibodies against kinesin (Muresan et al., 1999). Unfortunately, it is not possible to label AI cells of the macaque monkey selectively. However, AI cells of the rabbit retina can be labeled by their uptake of serotonin (5-HT) (Holmgren-Taylor, 1982; Sandell and Masland, 1986; Vaney, 1986; Sandell et al., 1989). We therefore studied the expression of GluRs by AI cells in the rabbit 
retina. Because AII cells of the rabbit retina are immunoreactive for calretinin (Massey and Mills, 1999) and RB cells are immunoreactive for PKC (Greferath et al., 1990), all three members of the dyad could be studied by immunocytochemical methods.

\section{MATERIALS AND METHODS}

Animals and tissue preparation. The monkey retinas that were studied were from adult macaque monkeys, Macaca fascicularis, that were killed after electrophysiological experiments unrelated to those described here. All procedures were approved by the local animal care committee and were in accordance with the law for animal experiments issued by the German government (Tierschutzgesetz). The animals were given a lethal dose of pentobarbitone, and the eyes were quickly removed. The posterior eyecup was immersion-fixed in 2 or $4 \%$ paraformaldehyde in $0.1 \mathrm{M}$ phosphate buffer (PB), $\mathrm{pH} 7.4$, for 10-30 min. After fixation, the retinas were dissected from the eyecup and cryoprotected in graded sucrose solutions $(10,20$, and $30 \%)$. Retinal pieces were sectioned vertically at 14 $\mu \mathrm{m}$. Albino rabbits were deeply anesthetized with Ketanest and Rompun before being given a lethal injection of pentobarbitol. The eyes were quickly removed and prepared as described above for the monkey retinas. In some cases, the eyecup was incubated first in $25 \mu \mathrm{M}$ 5-hydroxytryptamine (5-HT) (Sigma, Taufkirchen, Germany) in continuously carboxygenated Ames medium for $1 \mathrm{hr}$ before fixation and cryoprotection.

For electron microscopy (EM), it was necessary to make a compromise between the preservation of the tissue and the protection of the antigenicity. Epitopes of proteins aggregated in postsynaptic densities are very fixation-sensitive; to maximize immunoreactivity, the tissue received only minimal fixation (4\% paraformaldehyde; $30 \mathrm{~min}$ ) and was cryoprotected in up to $50 \%$ sucrose solution.

Antisera. Rod bipolar cells were labeled with antibodies against PKC $\alpha$ : mouse anti-PKC (clone MC5; Biodesign International, Saco, ME) and goat anti-PKC (Santa Cruz Biotechnology, Santa Cruz, CA). AII amacrine cells were labeled with antibodies against calretinin (CR): mouse anti-CR and goat anti-CR (Chemicon, Temecula, CA). In addition, in the rabbit retina, AI amacrine cells were labeled by uptake of 5-HT, which was then visualized using an antibody against 5-HT, mouse anti-5-HT (Dako, Glostrup, Denmark). Specific antibodies against glutamate receptor subunits were used: rabbit anti-GluR1, rabbit anti-GluR2, rabbit anti-GluR2/3, rabbit anti-GluR4, and rabbit anti- $\delta 1 / 2$ (Chemicon). Ribbon synapses were labeled using a marker for the membrane traffic motor protein kinesin, mouse anti-kinesin II (Babco, Richmond, CA). The postsynaptic density protein PSD-95 was labeled with mouse anti-PSD-95 (Upstate Biotechnology Inc., Lake Placid, NY), and the glutamate receptor-interacting protein (GRIP) was labeled with rabbit anti-GRIP (kind gift from Dr. M. Sheng, Massachusetts General Hospital, Boston, MA) and mouse anti-GRIP (Transduction Laboratories, Lexington, $\mathrm{KY}$ ).

Light microscopic immunocytochemistry. The antisera were diluted as follows: mouse anti-PKC, 1:100-1:2000; goat anti-PKC, 1:2000; mouse anti-CR, 1:1000-1:2000; goat anti-CR, 1:1000; 5-HT, 1:1000; GluR1, 1:25-1:50; GluR2, 1:50; GluR2/3, GluR4, and $\delta 1 / 2,1: 100$; kinesin II, 1:50; PSD-95, 1:1000; rabbit anti-GRIP, 1:500; mouse anti-GRIP, 1:5000; in PBS, $\mathrm{pH} 7.4$, containing $3 \%$ normal goat serum (NGS), $1 \%$ bovine serum albumin (BSA), and $0.5 \%$ Triton X-100. Immunocytochemical labeling was performed using the indirect fluorescence method. After preincubation in PBS containing 10\% NGS, $1 \%$ BSA, and $0.5 \%$ Triton X-100, the sections were incubated overnight in the primary antibodies, followed by incubation $(1 \mathrm{hr})$ in the secondary antibodies, which were conjugated either to Alexa TM 594 (red fluorescence) or Alexa TM 488 (green fluorescence) (purchased from Molecular Probes, Eugene, OR).

In double-labeling experiments, sections were incubated in a mixture of primary antibodies followed by a mixture of secondary antibodies. In the case of the PKC and CR antibodies raised in goat, we have used normal donkey serum (NDS) instead of NGS plus Alexa TM 488 donkey anti-goat (Molecular Probes) and Cy3 donkey anti-rabbit (Jackson ImmunoResearch, West Grove, PA) as secondary antibodies.

In the triple-labeling experiments, Cy5 donkey anti-mouse (Jackson ImmunoResearch) was used in addition to the Alexa TM 488 and Cy3 secondary antibodies. All secondary antibodies were diluted 1:500 in PBS containing $3 \%$ NGS, $1 \%$ BSA, and $0.5 \%$ Triton X-100.

Fluorescent specimens were viewed using a Zeiss (Oberkochen, Germany) Axiophot microscope equipped with a fluorescent filter set that was wedge-corrected, i.e., shifting from one filter to the other filter did not introduce spatial displacements. For the high-power fluorescence micrographs, a Plan-Neofluar $100 \times / 1.3$ objective was used. Black-andwhite digital images were taken with a cooled CCD camera (Spot 2; Diagnostic Instruments, Sterling Heights, MI). Using the Metaview software (Universal Imaging, West Chester, PA), images taken with the red and green fluorescence filters were pseudocolored and superimposed (see Figs. $2 F-K, 4 B-D, F-H$ ). Confocal micrographs were taken using a Leica TCS SP confocal microscope equipped with a krypton-argon laser or a Zeiss LSM5 Pascal confocal microscope equipped with an argon laser and a HeNe laser. High resolution scanning was performed with a Plan-Apochromat $63 \times / 1.4$ objective and with $1024 \times 1024$ or $2048 \times$ 2048 pixels. Single optical sections are shown in Figures 1, 4, $A$ and $E, 5$, and 7. Serial sections were also taken (z-axis step size, $0.5 \mu \mathrm{m})$ and the stacks were subsequently collapsed into a single plane (see Fig. $2 A-E ; 10$ sections of $0.5 \mu \mathrm{m}$.) The brightness and the contrast of the final images were adjusted using Adobe Photoshop 5.5.

Postembedding immunoelectron microscopy. The slam-freezing and cryosubstitution methods used in this study are a modification of those previously described (Baude et al., 1993). Briefly, small pieces of retina were slam-frozen onto a precooled copper block using a Reichert MM80 U (Leica, Bensheim, Germany). The frozen specimens were transferred then to a cryosubstitution unit (Reichert AFS; Leica) and placed into a solution of $0.5 \%$ uranyl acetate $(\mathrm{w} / \mathrm{v})$ in $100 \%$ methanol at $-90^{\circ} \mathrm{C}$. After $36 \mathrm{hr}$, the temperature was increased stepwise to $-30^{\circ} \mathrm{C}$. Then, the samples were washed several times in precooled methanol and progressively infiltrated with Lowicryl HM20 (Chemische Werke Lowi GmbH, Waldkraiburg, Germany) (1:1 Lowicryl to methanol, 90 min; 2:1 Lowicryl to methanol, $90 \mathrm{~min}$; 100\% Lowicryl, $90 \mathrm{~min}$; 100\% Lowicryl, overnight). Polymerization was achieved by exposure to UV light for $12 \mathrm{hr}$.

Ultrathin sections were cut and collected on Formvar-coated nickel grids. The sections were incubated first in $0.05 \mathrm{M}$ Tris-buffered saline (TBS), $\mathrm{pH}$ 7.6, for $15 \mathrm{~min}$, followed by a blocking solution containing $10 \%$ NDS, $0.1 \%$ cold-water fish skin (CWSC) gelatin (Aurion, Wageningen, The Netherlands) and TBS with $0.1 \%$ Triton (TBST) for $20 \mathrm{~min}$. Sections were incubated overnight in primary rabbit anti-GluR2/3 1:10 alone or in a mixture of GluR2/3 and goat anti-CR 1:500 diluted in 1\% NDS, $0.1 \%$ CWSC gelatin, and TBST. After washing in TBS, sections were incubated for $2 \mathrm{hr}$ in secondary donkey anti-rabbit IgG conjugated to $12 \mathrm{~nm}$ gold (Jackson ImmunoResearch) diluted 1:20 in 1\% NDS, $0.1 \%$ CWSC gelatin, and TBST or in a mixture of donkey anti-goat IgG conjugated to $12 \mathrm{~nm}$ gold and donkey anti-rabbit IgG conjugated to $6 \mathrm{~nm}$ gold. After further washing in TBS and PB, the sections were fixed for 5 min in $2 \%$ glutaraldehyde in PB, washed in distilled water, and counterstained with uranyl acetate and lead citrate. Then, the grids were viewed with a Zeiss EM10 electron microscope.

\section{RESULTS \\ AMPA-receptor subunits at the rod bipolar cell axon terminal}

$\mathrm{RB}$ cells of a macaque monkey retina are labeled in Figure $1 \mathrm{~A}$ for $\mathrm{PKC} \alpha$. RB cell dendrites contact rod spherules in the outer plexiform layer (OPL), and RB cell axons descend into the lower (inner) part of the IPL where they terminate in lobular swellings (Fig. $1 A$ ). In the primate retina, PKC immunoreactivity is also found in an on-cone bipolar cell type (Grünert et al., 1994; Mills and Massey, 1999); however, the labeling is weaker than that of $\mathrm{RB}$ cells, and the axon terminals occupy a narrow band above the RB axon terminals (Fig. 1A, double-headed arrow). The same section was also labeled for GluR4 (Fig. 1B), and immunoreactive puncta are found at the positions of the cone pedicles in the OPL (Haverkamp et al., 2001) and throughout the IPL. Such punctate staining of transmitter receptors in the IPL has been shown previously to represent a clustering of the receptors in postsynaptic densities (Brandstätter et al., 1998; Wässle et al., 1998). Few output synapses have been described along the descending axons of the RB cells, the majority being found on their lobular axon terminals (Grünert and Martin, 1991). Most of the GluR4 clusters in the IPL are, therefore, associated with off- and on-cone bipolar cell terminals; only those in the lower part of the IPL are expected to be postsynaptic to RB cells (Fig. 1B). Only this 

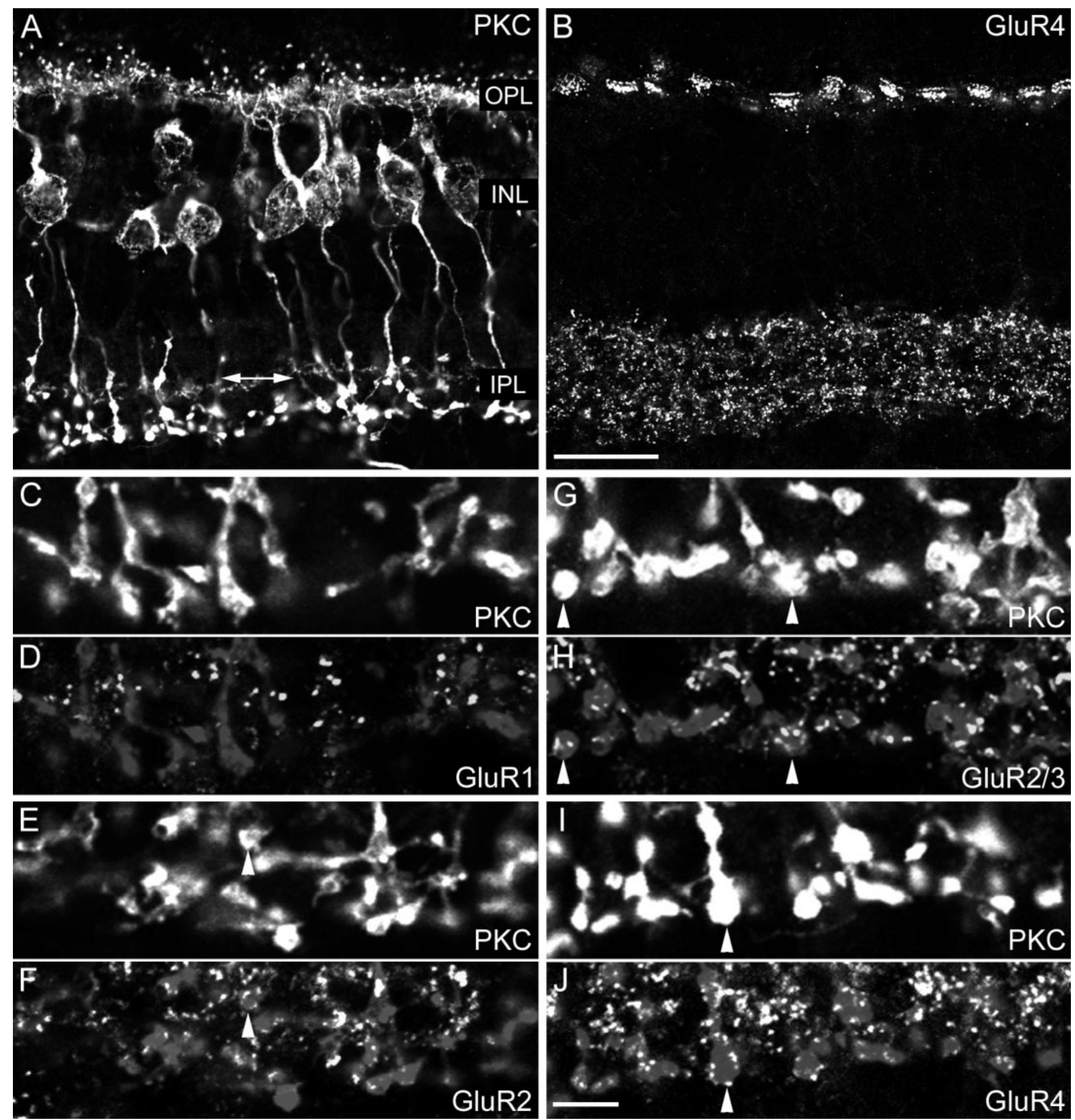

Figure 1. Localization of the AMPA receptor subunits GluR1, GluR2, GluR2/3, and GluR4 at the RB cell axon terminals of the macaque monkey retina. $A$, Fluorescence micrograph of a vertical section immunostained for PKC. The retinal layers are indicated. $O P L$, Outer plexiform layer; $I N L$, inner nuclear layer; $I P L$, inner plexiform layer; arrow, axon terminals of labeled cone bipolar cells. $B$, Same section as in $A$ immunostained for GluR4. $C, D$, The inner part of the IPL of a vertical section that was double-labeled for PKC $(C)$ and GluR1 $(D)$. The bright puncta in $D$ represent synaptic clusters of GluR1. The RB axon terminals are also shown faintly in $D$ (and in micrographs $F, H$, and $J$ ). $E$, $F$, The inner part of the IPL of a vertical section that was double-labeled for PKC $(E)$ and for the GluR2 subunit $(F)$. The arrowhead shows an axonal varicosity that is decorated by GluR2-immunoreactive puncta. $G, H$, The inner part of the IPL of a vertical section that was double-labeled for PKC $(G)$ and for the GluR2/3 subunit $(H)$. The arrowheads show axonal varicosities that are surrounded by GluR2/3-immunoreactive puncta. $I, J$, The inner part of the IPL of a vertical section that was double-labeled for PKC $(I)$ and for the GluR4 subunit $(J)$. The arrowhead shows an axonal varicosity that is covered by GluR4-immunoreactive puncta. Scale bars: $A, B, 20 \mu \mathrm{m} ; C-J, 5 \mu \mathrm{m}$. 
particular region is shown in the high-power micrographs of Figure $1, C-J$. A section that was double-labeled for PKC and GluR1 is shown in Figure 1, $C$ and $D$, respectively. There are no GluR1 immunoreactive puncta in close apposition to the RB axon terminals, and we conclude that this subunit is not expressed postsynaptically to RB cells. A section that was double-labeled for PKC and GluR2 (Fig. 1E,F) shows a few puncta in register with the RB axon terminals (arrowheads). The section in Figure 1, $G$ and $H$, was double-labeled for PKC and the GluR2/3 subunits. The RB axon terminals are decorated by many GluR2/3 immunoreactive puncta (arrowheads). The same holds true for a section that was double-labeled for PKC and the GluR4 subunit (Fig. $1 I, J)$. Most GluR4 immunoreactive puncta in this inner part of the IPL coincide with RB axon terminals (arrowhead). The results presented in Figure 1 suggest that AMPA receptors are aggregated in postsynaptic densities at the RB axon terminals. Clusters containing the GluR2/3 and/or the GluR4 subunits are observed most frequently there. The GluR1 subunit is not found in association with RB axon terminals.

To show more directly the clustering of AMPA receptors at the $\mathrm{RB}$ cell dyad, we triple-labeled a section through the rabbit retina for PKC, GluR2/3, and kinesin (Fig. 2). Kinesin has recently been shown to be a marker of the synaptic ribbons both in the OPL and the IPL (Muresan et al., 1999). In the low-power micrograph (Fig. $2 A$ ), the OPL appears overexposed because of the very strong red immunofluorescence of the horseshoe-shaped ribbons in the rod spherules (arrows). The rod bipolar cells are shown in blue, and their descending axons terminate in the lower IPL. The IPL is filled with red (kinesin), green (GluR2/3), and yellow puncta (kinesin-GluR2/3 double-labeled). The RB axon terminal region, indicated by a box, is magnified in Figure $2, B-E$, and the $\mathrm{RB}$ axon terminals (Fig. 2B), the ribbons (Fig. 2C), and the GluR2/3 clusters (Fig. 2D) are shown separately or superimposed (Fig. $2 E$ ). Observing this region through all four micrographs shows that most of the ribbons in this lower part of the IPL coincide with RB axon terminals and thus represent RB cell dyads. Moreover, there is basically a one-to-one relation between the ribbons (Fig. 2C, red puncta) and the GluR2/3 clusters (Fig. 2D, green puncta). At every dyad of RB cell axon terminals, AMPA receptors are expressed. The same result was also found for RB axon terminals of the macaque monkey retina (data not shown).

Next, we wanted to know the subunit composition of the AMPA receptors expressed at $\mathrm{RB}$ axon terminals. Because both the GluR2/3 and the GluR4 antibodies were raised in rabbits, we could not perform direct double-labeling and thus used a different approach. We have shown previously that the postsynaptic density protein PSD-95 is aggregated at postsynaptic densities of RB cell dyads (Koulen et al., 1998a). PSD-95 belongs to a family of GluR-clustering molecules (for review, see Kennedy, 2000; Scannevin and Huganir, 2000). We double-labeled sections through the macaque monkey retina for PSD-95 and GluR2/3 (Fig. $2 F-$ $H$ ), and for PSD-95 and GluR4 (Fig. $2 I-K$ ). All GluR2/3 immunoreactive puncta coincided with PSD-95 immunoreactive clusters. The same holds true for GluR4 immunoreactive puncta. There were only a few PSD-95 immunoreactive clusters left that were not in register with GluR2/3 or GluR4 puncta. This shows that the great majority of GluR2/3 and GluR 4 puncta must be in register and occur in the same postsynaptic density. This would suggest that most AMPA receptors expressed at the RB cell dyad are composed of the GluR2/3 and the GluR4 subunits. Finally, PSD-95 appears to be a reliable marker for AMPA receptors at RB cell dyads.
We also studied the localization of AMPA receptors at RB cell dyads by pre-embedding and post-embedding immunocytochemistry and EM. In the EM micrographs, as a rule, only one of the two postsynaptic elements expressed an AMPA receptor subunit (Fig. 3). Only rarely were both members of the dyad labeled. Unfortunately the tissue preservation was compromised because of the necessity of using short fixation times. For this reason, we were not able in the EM micrographs to observe reciprocal synapses in the vicinity of the dyads that would indicate that the labeled processes belong to AI amacrine cells. In addition, we could not recognize AII amacrine cells from the characteristic organelles in their cytoplasm (Kolb and Famiglietti, 1974). However, it will be shown later that we were able to recognize AII amacrine cells in EM micrographs of calretinin-labeled sections.

\section{Further GluR receptor subunits at the rod bipolar cell axon terminal}

Our laboratory has described the expression of the KA receptor subunit KA2 at the RB cell dyads of the rat retina (Brandstätter et al., 1997). Only one of the two members of the dyad expressed KA2 immunoreactivity. Brandstätter et al. (1997) also localized the KA receptor subunit GluR6/7 and the orphan receptor subunits $\delta 1 / 2$ to one member of the RB cell dyad. We applied the same KA2 antiserum to the monkey; however, as reported elsewhere, this antiserum showed a prominent cross-reactivity with some unknown antigen in these retinas and did not recognize the correct protein (Haverkamp et al., 2001). We studied the distribution of the KA receptor subunit GluR5 in the monkey retina and observed synaptic labeling only in the OPL, with no labeling in the IPL (Haverkamp et al., 2001). We also applied the GluR6/7 antiserum; however, once again this antiserum showed an unusual pattern of staining and was not further analyzed here. However, we were able to observe a reliable immunostaining of monkey and rabbit retinas for the $\delta 1 / 2$ subunits.

Originally, the $\delta$ subunits were named orphan receptors, because the recombinantly expressed protein lacks all channel activity (Araki et al., 1993; Lomeli et al., 1993). However, recently it has been shown that the $\delta$ subunits are clustered at the dendritic spines of cerebellar Purkinje cells (Landsend et al., 1997). Moreover, a mutation of the $\delta 2$ subunit in the Lurcher mouse results in an opening of channels even in the absence of glutamate (Zuo et al., 1997). All this suggests that the $\delta$ subunits, together with an unknown subunit partner, form cation channels that are activated by glutamate (Seeburg, 1997; Kohda et al., 2000).

Figure $4 A$ shows the $\mathrm{RB}$ cell axon terminals in a section through the monkey retina that was double-labeled for PKC and for the $\delta 1 / 2$ subunits. The $\delta$ label is punctate, suggesting that, comparable to the cerebellum (Landsend et al., 1997; Bergersen et al., 2001), the $\delta$ subunits are clustered in postsynaptic densities. In addition, many $\delta$ clusters appear to be in close apposition to the $\mathrm{RB}$ cell axon terminals (Fig. $4 A$, arrow) that have been shown in the rat retina by EM to represent an expression of the $\delta 1 / 2$ subunits at the dyads (Brandstätter et al., 1997). It now needs to be clarified (1) which other GluR subunits are the partners of the $\delta$ subunits at the RB cell terminals and (2) which of the two postsynaptic elements, AI or AII cells, express the $\delta$ subunits.

Because most of the antibodies against the AMPA receptor subunits, as well as the antibodies against the $\delta 1 / 2$ subunits, were raised in rabbits, we could not perform a direct comparison by double-labeling experiments. However, as shown before, PSD-95 appears to be aggregated together with the GuR2/3 and the GluR4 subunits (Fig. 2). Therefore, the possible colocalization of 


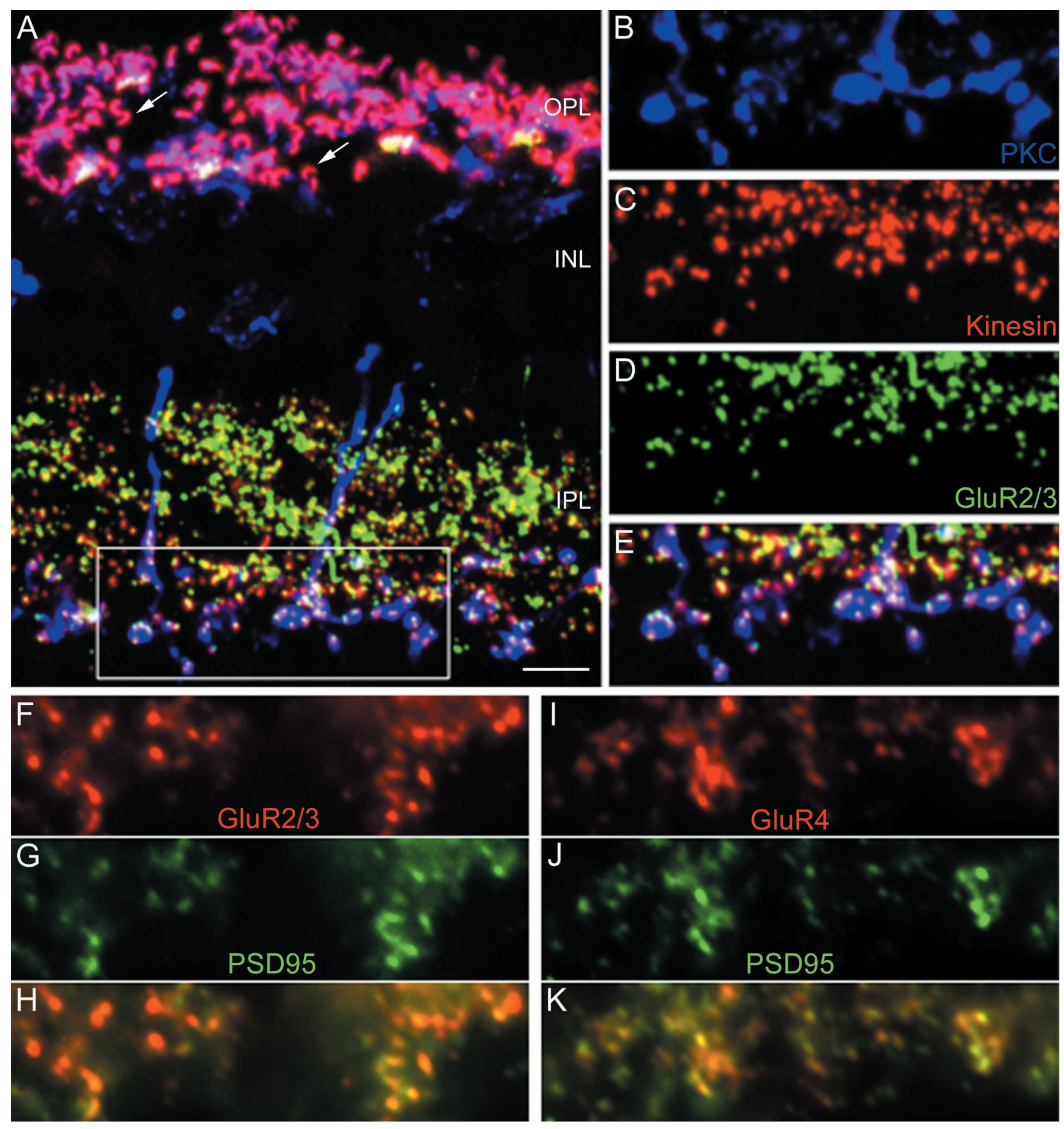

Figure 2. A-E, Confocal micrographs of a section through the rabbit retina that was triple-labeled for PKC (blue), kinesin (red), and GluR2/3 ( green). $A$, Low-power micrograph showing the retinal layers. The arrows in the OPL indicate the ribbons of rod spherules. The inner part of the IPL is shown at higher magnification in $B-E$. B, PKC-immunostained RB cell axon terminals. $C$, Kinesin-labeled presynaptic ribbons. $D$, GluR2/3-labeled hot spots. $E$, Superposition of $B, C$, and $D$. All GluR2/3-immunoreactive puncta in the bottom half of the IPL coincide with kinesin-labeled ribbons and PKC-labeled RB cell axon terminals. $F-H$, Fluorescence micrographs of the inner part of a macaque monkey IPL that was double-labeled for GluR2/3 (red) and PSD-95 (green). The superposition of the immunoreactive puncta in $H$ shows that all GluR2/3 puncta coincide with PSD-95 puncta. $I-K$, Fluorescence micrographs of the inner part of a macaque monkey IPL that was double-labeled for GluR4 (red) and PSD-95 (green). K, All GluR4immunoreactive puncta coincide with PSD-95 labeled puncta. Scale bar (shown in $A$ ): $A, 10 \mu \mathrm{m} ; B-E, 7.5 \mu \mathrm{m} ; F-K, 2.5 \mu \mathrm{m}$. 


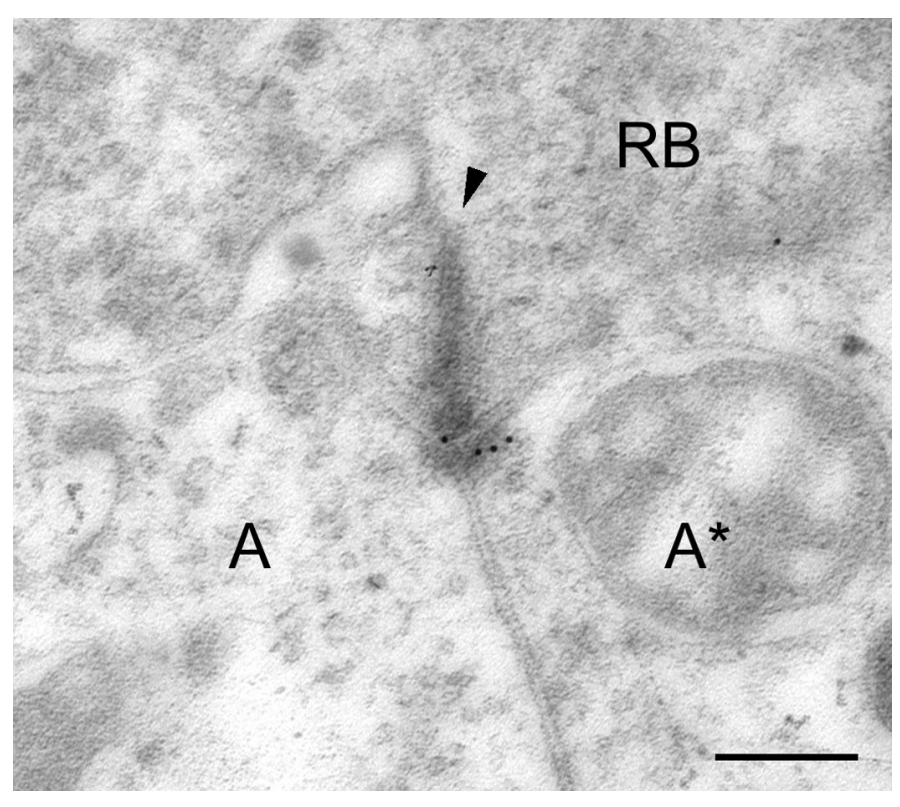

Figure 3. Electronmicrograph of a section through a RB cell dyad of a macaque monkey retina. The section was immunolabeled for GluR2/3 using postembedding immunocytochemistry and secondary antibodies that were coupled to gold particles of $12 \mathrm{~nm}$ diameter. $R B$, Axon terminal; $A$, unlabeled postsynaptic process; $A^{*}$, labeled postsynaptic process; arrowhead, presynaptic ribbon. Scale bar, $0.2 \mu \mathrm{m}$.

the $\delta 1 / 2$ subunits with the AMPA receptor subunits was studied by double-labeling sections for $\delta 1 / 2$ and PSD-95 (Fig. $4 B-D$ ). Comparison of panels $B-D$ in Figure 4 shows that $\delta 1 / 2$ clusters and PSD-95 clusters are not colocalized, suggesting that they are aggregated at different postsynaptic densities. Therefore, it appears unlikely that $\delta 1 / 2$ subunits together with AMPA receptor subunits coassemble at the RB cell dyads. Close inspection of the labeled PSD-95 and $\delta 1 / 2$ immunoreactive puncta in Figure 4 (encircled) shows that they often occur as close neighbors, suggesting that one such pair represents the expression by the two members of the dyad. Apparently PSD-95 and AMPA receptors are expressed by one postsynaptic member of the dyad, whereas the $\delta 1 / 2$ subunits appear to be clustered at the other member of the dyad.

\section{Synapse-associated proteins at the RB cell dyad}

In addition to PSD-95, which was found to be associated with AMPA receptors at the RB cell dyads, we localized another synapse-associated protein. GRIP has been described in other parts of the CNS to be associated with glutamate receptors (Dong et al., 1997) and possibly with GABA receptors (Dong et al., 1999).

A section through the lower part of the IPL of a macaque monkey retina that was double-labeled for PKC and GRIP is shown in Figure $4 E$. The GRIP label is punctate, suggesting it is aggregated in postsynaptic densities as has been shown in other parts of the CNS (Dong et al., 1997, 1999; Wyszynski et al., 1998; Burette et al., 2001). Many of the GRIP hot spots (Fig. 4E, arrows) are associated with $\mathrm{PKC}$ immunoreactive axon terminals of RB cells, similar to the $\delta 1 / 2$ subunit (Fig. $4 A$ ) and the AMPA subunits (Fig. $1 H, J$ ). We also double-labeled sections for the ribbon marker kinesin and for GRIP and observed a GRIP immunoreactive hot spot at the great majority of the ribbons (data not shown). Together, these results indicate that GRIP is aggregated in postsynaptic densities at the RB cell dyads.
This raises the following question: is GRIP clustered in the same postsynaptic densities as PSD-95? A section through the inner IPL of a macaque monkey retina was double-labeled for GRIP (Fig. 4F) and for PSD-95 (Fig. 4G). Both GRIP and PSD-95 show a punctate immunofluorescence; however, the superposition of the puncta (Fig. $4 H$ ) shows that they do not coincide, suggesting that they are clustered at different postsynaptic densities. Close inspection of the groups of puncta that are encircled in Figure 4, $F-H$, suggests that they often occur as neighbors in the two postsynaptic members of the dyads. We also double-labeled sections for GRIP and the $\delta 1 / 2$ subunits (Fig. $4 I-K)$ and observed that the majority of $\delta 1 / 2$ immunoreactive puncta coincided with GRIP immunoreactive clusters. However, the coincidence rate between GRIP and the $\delta 1 / 2$ subunits is not as high as that observed for PSD-95 and AMPA subunits (Fig. $2 F-K)$. There are some GRIP hot spots not associated with $\delta 1 / 2$ and vice versa, suggesting that GRIP is not involved only with the clustering of $\delta 1 / 2$ subunits.

The analysis of the localization of the AMPA and $\delta 1 / 2$ subunits and of the clustering proteins PSD-95 and GRIP using light microscopy represents an undertaking at the limits of the resolution of light microscopy. However, such an analysis has the advantage that many more dyads can be observed than by the usual approach of EM serial reconstructions of this complex synapse (Marc and Liu, 2000). On the basis of the results presented so far, we conclude that AMPA receptor subunits and PSD-95 are expressed together in one postsynaptic member of the dyad, whereas the $\delta 1 / 2$ subunits and GRIP appear to be clustered in the other member of the dyad.

\section{The postsynaptic partners at the RB cell dyad}

AII cells express the AMPA receptor subunits

Next, we wanted to know which of the two postsynaptic elements at the RB cell dyads express AMPA receptors. Qin and Pourcho (1999a,b) have shown in the cat retina that AMPA receptors are expressed by AII amacrine cells at the RB cell dyad. In both the monkey and the rabbit retina, AII amacrine cells are immunoreactive for the calcium-binding protein calretinin (Wässle et al., 1995; Massey and Mills, 1999; Mills and Massey, 1999). A section through a macaque monkey retina that was double-labeled for calretinin and GluR4 is shown in the low-power micrographs of Figure 5, $A$ and $B$. The typical bistratified morphology of the AII amacrine cells, with lobular dendrites in the outer IPL and distal dendrites in the inner IPL, is apparent in Figure $5 A$. GluR4 immunoreactivity is present throughout the IPL (Fig. $5 B$ ); hence AII cells may well receive input through GluR4 subunits both at their lobular and distal dendrites. However, in the context of the present study, we focus on the RB input into the distal dendritic tree (Fig. $5 A, B$, squares). Figure $5, C-E$, shows a section through this region at higher magnification. Close inspection shows that many GluR4 immunoreactive puncta are in register with small varicosities at which AII amacrine cell dendrites apparently receive input from RB cell axon terminals (arrows). However, one might argue that because of the close apposition of AI and AII processes at the dyad it is impossible by light microscopy to decide whether the GluR4 hot spots are on the AI cell or the AII cell.

Therefore, this result was corroborated by EM double-labeling experiments (Fig. 6). Secondary antibodies coupled to large gold particles of $12 \mathrm{~nm}$ diameter were applied to reveal the calretinin immunolabeling. As shown in Figure 6, $A$ and $B$, only one of the two amacrine cell processes at the RB dyad was labeled, thus representing the AII amacrine cell. Secondary antibodies coupled 

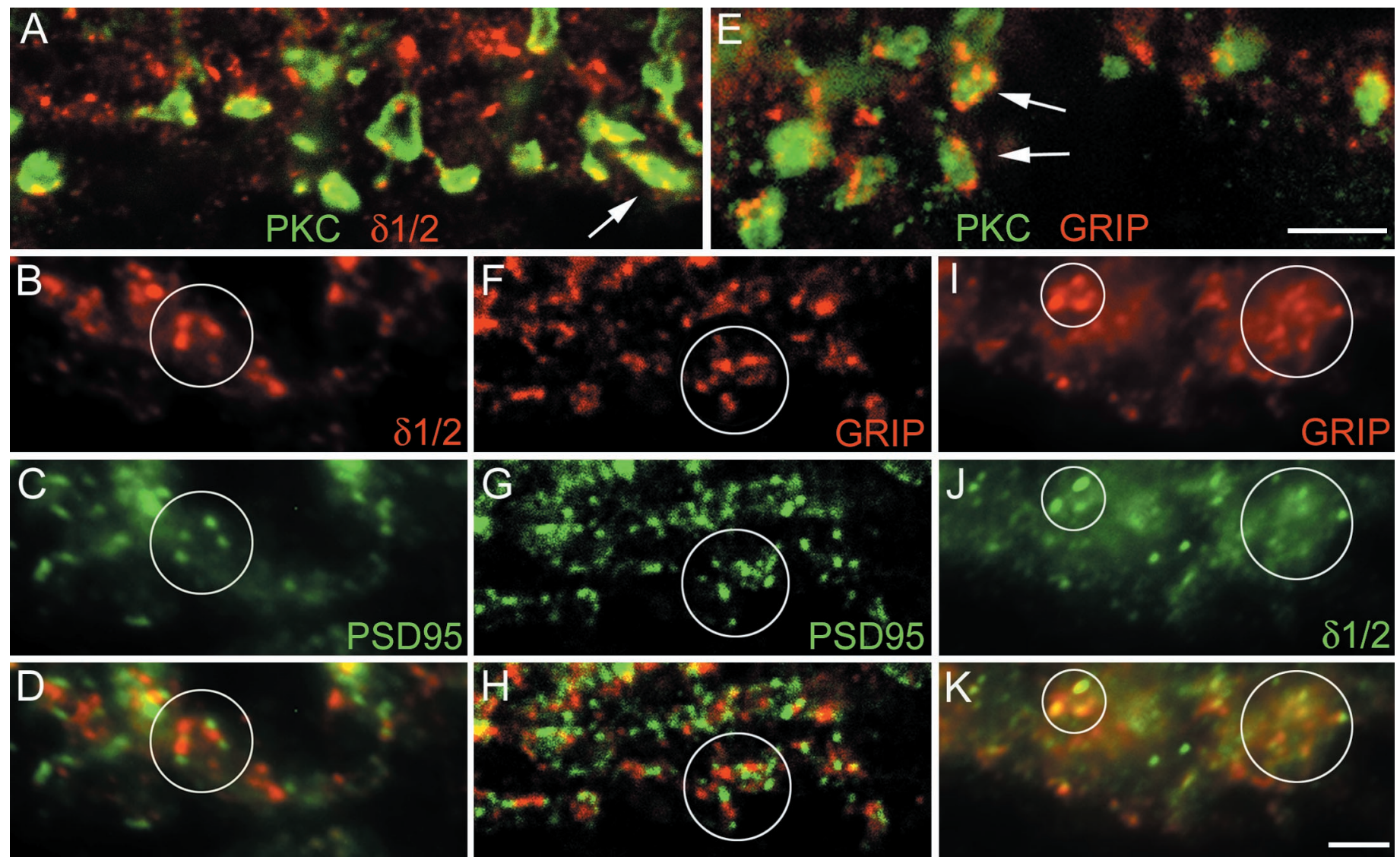

Figure 4. A, Confocal fluorescence micrograph of a vertical section through the inner part of the IPL of a macaque monkey retina that was double-labeled for PKC (green) and the $\delta 1 / 2$ subunit (red). Many $\delta 1 / 2$ immunoreactive puncta coincide with the RB axonal varicosities (arrow). B-D, Fluorescence micrograph of a section through the inner IPL of a macaque monkey retina that was double-labeled for $\delta 1 / 2$ (red) and PSD-95 (green). The superposition in $D$ shows that the puncta are not in register. $E$, Confocal fluorescence micrograph of a vertical section through the inner IPL of a macaque monkey retina that was double-labeled for PKC ( green) and for GRIP (red). Many GRIP-immunoreactive puncta coincide with RB cell axonal varicosities (arrows). $F-H$, Fluorescence micrograph of a section through the inner IPL of a macaque monkey retina that was double-labeled for GRIP (red) and PSD-95 (green). The superposition in $H$ shows that the puncta are not in register. $I-K$, Fluorescence micrographs of a section through the inner IPL of a macaque monkey retina that was double-labeled for GRIP (red) and $\delta 1 / 2$ ( green). The superposition in $K$ shows that many puncta are in register. The circles indicate groups of puncta to facilitate comparison between the micrographs. Scale bars: $A, E, 5 \mu \mathrm{m} ; B-D, F-K, 2.5 \mu \mathrm{m}$.

to small gold particles of $6 \mathrm{~nm}$ were applied to reveal the GluR2/3 immunolabeling (Fig. $6 A, B$ ). The small gold particles are aggregated in the AII amacrine cell processes, close to the synaptic ribbons (arrows). The postsynaptic areas are shown at higher magnification in Figure 6, $C$ and $D$, and the different sized gold particles can be discriminated more readily. A total of 18 doublelabeled RB cell dyads were studied. In 17 dyads, only one postsynaptic dendrite expressed calretinin, and in only one dyad both postsynaptic dendrites were found to be labeled. In 14 dyads, the expression of the GluR2/3 subunit was restricted to the calretininlabeled dendrite. In two dyads, GluR2/3 expression was observed in both the calretinin-labeled and -unlabeled dendrite. In one dyad, GluR2/3 label was observed in the calretinin-unlabeled dendrite. In the case of the dyad in which both postsynaptic dendrites expressed calretinin, both were immunoreactive for GluR2/3.

\section{AI cells express the $\delta 1 / 2$ subunits}

Unfortunately, there is no selective marker available for the AI cells of the macaque monkey retina. However, in the rabbit retina it has been shown that uptake of 5-HT is a selective marker for amacrine cell types that are members of the AI class at the RB cell dyads (Holmgren-Taylor, 1982; Sandell and Masland, 1986;
Vaney, 1986; Sandell et al., 1989). We therefore applied triplelabeling to sections through the rabbit retina to localize the GluRs to AI or AII cells. The section in Figure $7 A$ shows 5-HT labeled amacrine cell bodies (blue) and a dense plexus of dendrites in the lower IPL, which is the characteristic signature of these cells (Sandell and Masland, 1986; Vaney, 1986; Sandell et al., 1989). This plexus receives synapses from RB cells and provides GABAergic feedback synapses back onto the RB cell terminals. Many AII amacrine cells (green) are also labeled in Figure $7 A$. The $\delta 1 / 2$ immunoreactive clusters are shown in red (Fig. $7 A$ ). The area indicated by the frame in Figure $7 A$ is shown at higher magnification in Figure $7, B-D$. Figure $7 B$ shows only the calretinin and the $\delta 1 / 2$ labeling. Only two of the red $\delta 1 / 2$ puncta appear yellow (arrows), indicating that they coincide with the calretinin-labeled dendrites. Figure $7 C$ shows only the 5-HT and $\delta 1 / 2$ labeling. The majority of the red puncta appear purple, because they coincide with the blue, 5-HT labeled amacrine cell processes. The two red spots that were yellow in Figure $7 B$ are also purple in Figure $7 C$ (arrows). Finally, in Figure $7 D$ all three markers are shown. Once again, the two conspicuous spots are indicated by small arrows and they appear white in this micrograph, because they express all three labels (red,green, and blue). 

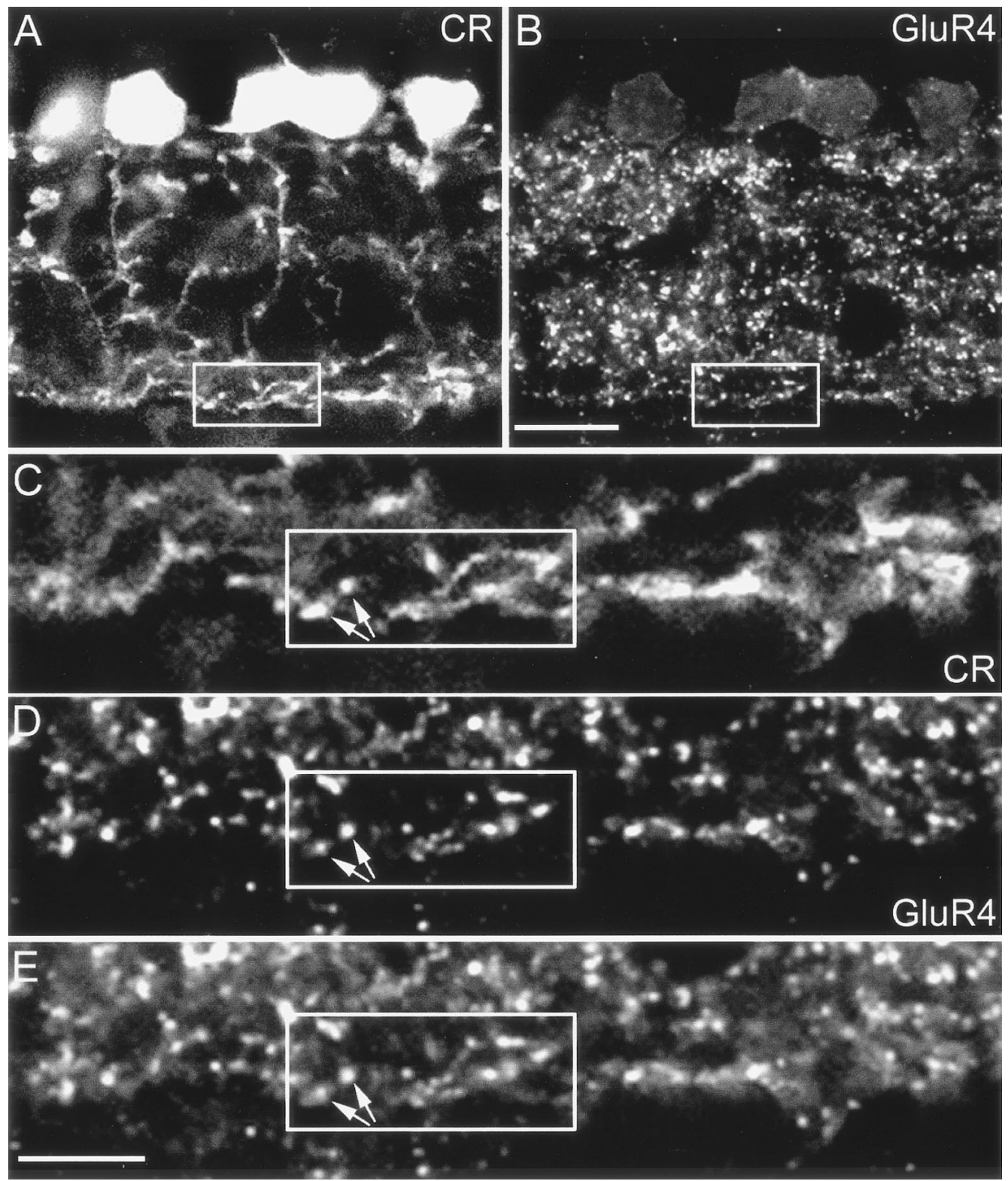

Figure 5. Localization of GluR4 immunoreactive puncta on AII amacrine cell dendrites. Confocal fluorescence micrographs that were double-labeled for calretinin $(C R)$ and the GluR4 subunit. $A$, Calretinin-labeled AII amacrine cells. $B$, GluR4-immunoreactive puncta of the same section as in $A$. The area indicated by the frame and the inner IPL are shown at higher magnification in $C-E$. $C$, The distal dendrites of AII amacrine cells form a dense network of processes in the inner IPL. $D$, Many GluR4-immunoreactive puncta are found in the same region. $E$, The superposition of $C$ and $D$ shows that many GluR4-immunoreactive puncta are in register with the small varicosities of AII cell dendrites (arrows). Scale bars: $A, B, 10 \mu \mathrm{m} ; C-E, 5 \mu \mathrm{m}$.

Clearly, in this instance we cannot decide whether these two $\delta 1 / 2$ hot spots are on the AII cells (green-labeled) or on the AI cells (blue-labeled). However, all other $\delta 1 / 2$ clusters appear to coincide with the AI cells.

Next, we triple-labeled a section through a rabbit retina for calretinin, 5-HT, and the AMPA receptor subunit GluR4 (Fig. $7 E$ ). One 5-HT-labeled AI amacrine cell body (blue) and several calretinin labeled AII cell bodies ( green) can be seen in the INL. In the lower part of the IPL, processes of AI and AII cells form a dense plexus at the position of RB axon terminals (Vaney et al., 1991; Fletcher and Wässle, 1999). Numerous GluR4 immunoreactive puncta are present throughout the IPL. The area indicated by the frame is shown at higher magnification in Figure $7, F-H$. Only the calretinin (green)-labeled descending dendrites of AII amacrine cells and the GluR4 immunoreactive puncta (red) are shown in Figure $7 F$. Close inspection shows that the puncta are aligned with the descending processes and also show some overlap. It is possible that calretinin does not fill the whole cytoplasm of the dendrites and, therefore, the GluR4 immunoreactive puncta turn only partially yellow. However, in this and in other sections we observed that GluR4 puncta were aligned along the AII cell dendrites. In Figure 7G, the 5-HT-labeled dendrites of AI cells and the GluR4 hot spots are shown in isolation. There is no close correspondence between the blue label and the red dots that would be comparable to Figure $7 F$. However, some of the GluR4 hot spots are in register with 5-HT-labeled processes (Fig. $7 G$, arrow). Finally, all three markers are shown together in the micrograph in Figure $7 H$, confirming that the GluR4 subunit is 

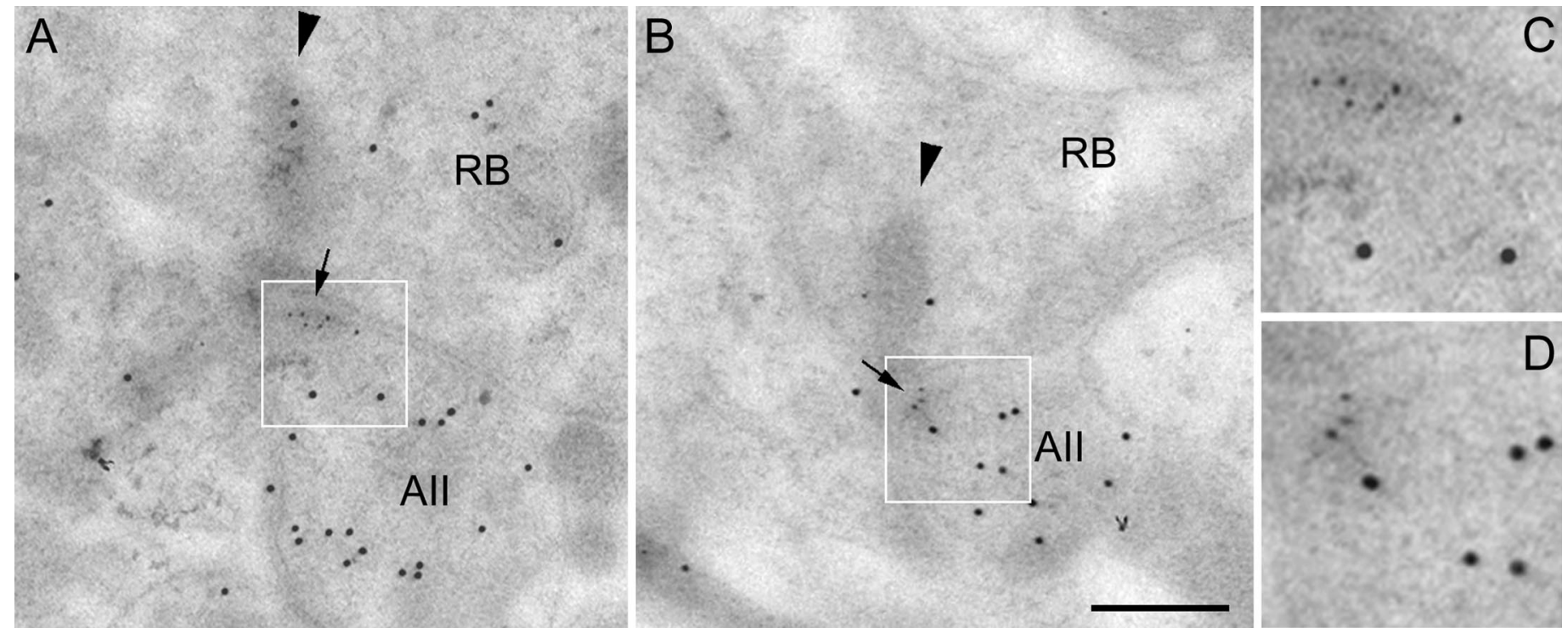

Figure 6. $A, B$, Electron micrographs of sections through two RB cell dyads of a macaque monkey retina. The sections were double-immunolabeled for GluR2/3 and calretinin using postembedding immunocytochemistry and secondary antibodies that were coupled to gold particles (GluR2/3, 6 nm; calretinin, $12 \mathrm{~nm}$ ). The insets indicated by the frames are shown at higher magnification in $C$ and $D$. The arrows point to the GluR2/3 label. $R B$, Axon terminal; $A I I$, calretinin-labeled AII amacrine cell dendrite. Arrowhead indicates the faintly stained synaptic ribbon. Scale bar: $A, B, 0.2 \mu \mathrm{m}$.

closely associated with the AII amacrine cells (green) and not so much with the AI cells (blue). However, some puncta (arrow) are in register with both the AI and AII processes.

We also performed double-labeling experiments for AI cells and GRIP (data not shown) and observed, comparable to the $\delta 1 / 2$ subunits, a close correspondence between the AI varicosities and the GRIP immunoreactive hot spots. AI cells often provide GABAergic feedback synapses onto RB cells, in close vicinity to the dyads (Strettoi et al., 1992). It is, therefore, to be expected that markers of these feedback synapses are found in close association with GRIP. We double-labeled sections for GRIP and bassoon (tom Dieck et al., 1998). Bassoon has been shown to be expressed at inhibitory synapses that $\mathrm{RB}$ axon terminals receive from amacrine cells (Brandstätter et al., 1999). We observed a close association, but not a coincidence of the GRIP immunoreactive puncta with the bassoon immunoreactive puncta (data not shown). The same holds true for sections that are double-labeled for GRIP and $\mathrm{GABA}_{\mathrm{C}}$ receptors.

Taken together, these results suggest that AMPA receptors and PSD-95 are preferentially expressed at the contacts between RB cells and AII cells, whereas the $\delta 1 / 2$ and the GRIP clusters are in register with the AI cells.

\section{DISCUSSION}

\section{The bipolar cell dyad}

At the cone bipolar cell dyad, the light signal is transferred to a ganglion cell dendrite and an amacrine cell process, which often makes a reciprocal synapse back onto the bipolar cell (Dowling and Boycott, 1966). At the rod bipolar cell dyad, two amacrine cells are the postsynaptic partners, the AI cell and the AII cell. Similar to the cone pathway, the AII cell is a "through conducting" neuron (Masland, 1986), whereas the AI cell provides a feedback synapse (Kolb and Famiglietti, 1974; Famiglietti and Kolb, 1975). Therefore, the two postsynaptic partners at bipolar cell dyads represent different pathways and have different functions; one is more involved with the transfer of the light signal, whereas the other one plays a modulatory role (Bloomfield and Dacheux, 2001).

Recent investigations of the transmitter receptors and postsynaptic density proteins expressed at the dyads have revealed molecular differences between the two pathways. The first hint came from the localization of the NMDA receptor NR2A subunit (Hartveit et al., 1994), which was expressed in only one partner of cone bipolar cell dyads, most likely the ganglion cell dendrite. Later, it was shown that the metabotropic glutamate receptor mGluR7 is expressed in only one postsynaptic member of the cone bipolar cell dyad and is not expressed postsynaptically at RB cells (Brandstätter et al., 1996). Similarly, mGluR2 and mGluR4 were restricted to one postsynaptic member of the dyad; however, they were associated with both cone and rod bipolar cells (Koulen et al., 1996). Kainate receptors were also selectively expressed in only one member of the dyad, both in cone and rod bipolar cells (Brandstätter et al., 1997; Qin and Pourcho, 2001). AMPA receptors were expressed also in only one postsynaptic dendrite, both in cone and rod bipolar cells (Qin and Pourcho, 1999a,b). In the case of the synapse-associated proteins PSD-95 and SAP102, localization was also restricted to one postsynaptic dendrite of cone and rod bipolar cells (Koulen et al., 1998a,b). All of this suggests that the two pathways postsynaptic to cone and rod bipolar cell dyads express different receptors to glutamate and that this molecular dichotomy results in different functional roles. The results also show that there is a difference between the cone bipolar cell and the rod bipolar cell pathways as the NMDA receptor subunits NR1, NR2A, NR2B, and mGluR7 are not expressed at the RB cell dyads (Brandstätter et al., 1996; Fletcher et al., 2000).

In this study, we have presented further evidence for the role of the dyad as a synapse that initiates two functionally and molecularly different pathways. The studies mentioned above analyzed the dyads primarily by pre-embedding immunocytochemistry and electron microscopy. In such studies, one has to worry about the tissue penetration of the antibodies and that only a few synapses can be observed. Hence, one can never be sure whether the 

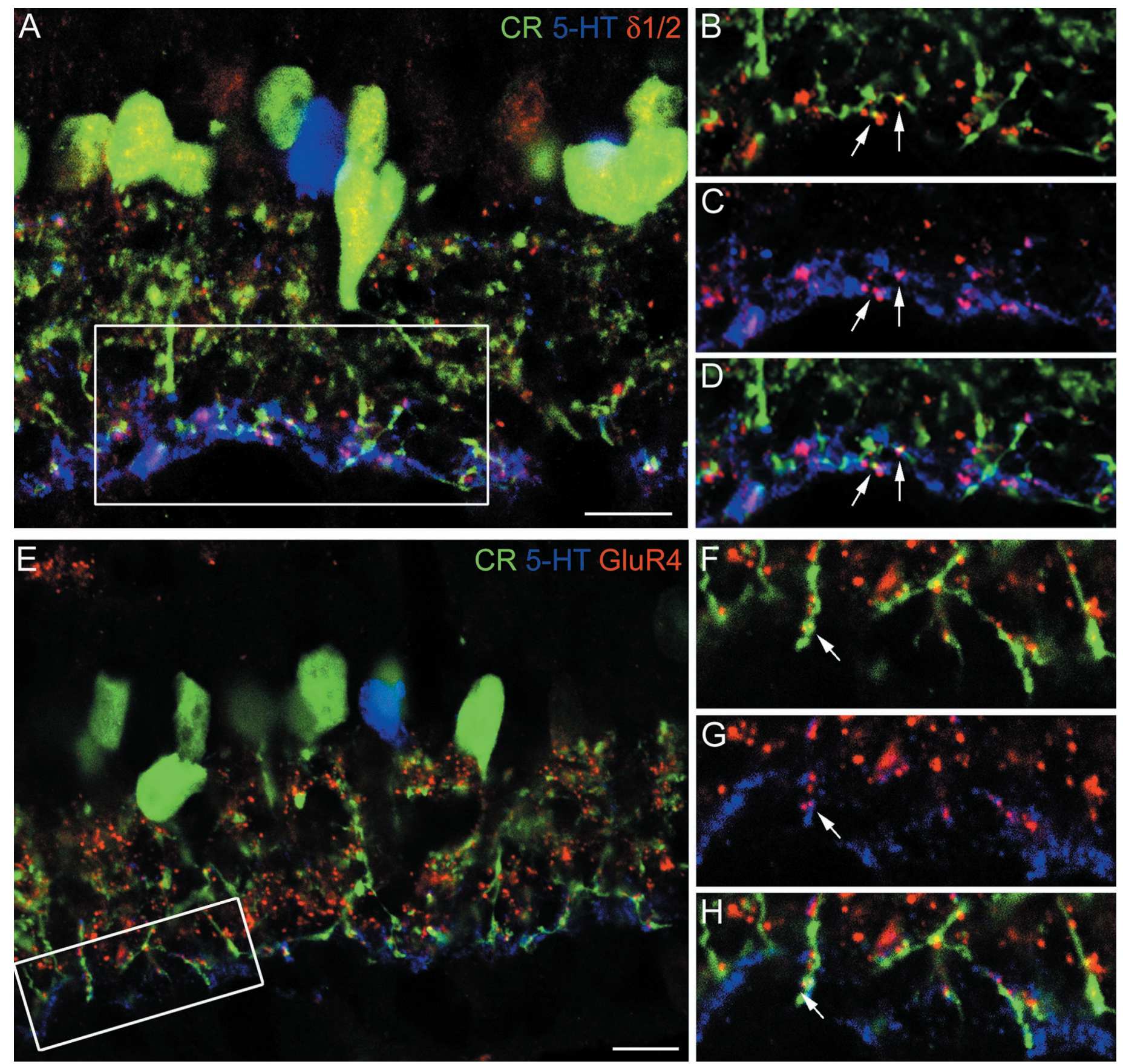

Figure 7. A, Confocal fluorescence micrograph of a vertical section through the inner part of a rabbit retina that was triple-labeled for calretinin $(C R$; green), serotonin (5-HT; blue), and the $\delta 1 / 2$ subunit (red). The inner IPL ( frame) is shown at higher magnification in $B-D$. B, The green AII cell dendrites and the red $\delta 1 / 2$ hot spots are not in register. Only two dots (arrows) coincide with green dendrites. $C$, The blue, 5-HT-labeled dendrites of AI amacrine cells coincide with the red $\delta 1 / 2$ hot spots, and as a consequence they appear purple. D, All three markers superimposed. The two dots (arrows) appear white. E. Confocal fluorescence micrograph of a vertical section through the inner part of a rabbit retina that was triple-labeled for calretinin $(C R$, green $)$, serotonin (5-HT, blue), and GluR4 subunit (red). The inner IPL (frame) is shown at higher magnification in $F-H$. F, The green AII cell dendrites and the red GluR4 puncta are often in register. $G$, The blue, 5-HT-labeled dendrites of AI cells are not in register with the GluR4 puncta. $H$, All three markers superimposed. The dot indicated by the arrow colocalizes both 5-HT and CR. Scale bars: $A, E, 10 \mu \mathrm{m}$.

labeling of only one postsynaptic partner of the dyad is because of technical limitations or whether it represents a real functional difference. In this study, we used confocal light microscopy and triple-labeling immunocytochemistry, and thus we were able to observe many more synapses and positively identify the postsynaptic partners. This analysis showed convincingly not only that AI and AII cells express different sets of GluRs but also that different postsynaptic density proteins are involved in clustering the receptors in the postsynaptic densities.

\section{The All cell pathway}

We could show by labeling the RB cell synaptic ribbons for kinesin and by confocal light microscopy that the AMPA receptor subunits GluR2/3 and GluR4, as well as PSD-95, are aggregated 
in postsynaptic densities at every individual dyad. Additional labeling of AII amacrine cells for calretinin demonstrated that these AMPA-PSD-95 clusters are expressed at the arboreal dendrites of AII amacrine cells. This result confirms and extends an EM study of the cat retina (Qin and Pourcho, 1999a,b) showing that AII amacrine cells, at their contacts with RB cells, express the GluR2/3 and GluR4 subunits. Also in agreement with studies in the cat retina (Qin and Pourcho, 1999a), we found no expression of GluR1 at RB cell dyads (Fig. $1 C, D$ ). However, in contrast to Brandstätter et al. (1997, their Fig. $7 A$ ), we conclude that the $\delta 1 / 2$ subunits are not expressed by AII cells. Recent electrophysiological recordings from AII amacrine cells in a slice preparation of the rabbit retina (Zhou and Dacheux, 2001) showed that activation of NMDA receptors did not elicit a current response. Kainate-AMPA receptor-mediated responses could be blocked by CNQX and GYKI52466, suggesting that they are mediated only by AMPA receptors.

\section{The Al cell pathway}

As mentioned in Results, for several technical reasons we could not study the localization of the kainate receptor subunits KA2 and GluR6/7 in the rabbit and macaque monkey retina. However, it has been shown before for the cat and rat retina that these subunits are expressed by only one postsynaptic member of the cone and rod bipolar cell dyad (Brandstätter et al., 1997; Qin and Pourcho, 2001). In this paper, by using confocal light microscopy and specific markers, we could show that the $\delta 1 / 2$ subunit is aggregated at the RB cell dyads, most likely at their contacts with AI amacrine cells. We have also presented evidence that the synapse-associated protein GRIP is most likely aggregated at these AI cell contacts. Together, all of this evidence suggests a clear-cut molecular difference between the AII contacts involving AMPA receptors and PSD-95 and the AI contacts involving the $\delta 1 / 2$ subunit and GRIP. We suggest that the subunits KA1/2, GluR6/7, and $\delta 1 / 2$ form heteromeric channels of the kainate type (Kohda et al., 2000) and that these receptors provide the signal transfer between RB cells and AI cells. However, because AI cells comprise several different types (Sandell and Masland, 1986; Sterling and Lampson, 1986; Vaney et al., 1991), it is possible that kainate receptors with different subunit combinations are expressed by these different AI cell types. This would create further diversity of the signal transfer at the RB cell dyads.

The glutamate receptors of AI amacrine cells have recently been studied by patch-clamp recordings from rat retina slices (Menger and Wässle, 2000). It was found that non-NMDA receptors mediate the responses to glutamate. A similar result has been reported by Hartveit (1999). Although specific antagonists to distinguish AMPA and kainate receptors were not applied, it was noticed that the CNQX and NBQX, which usually block these receptors, reduced the responses to only $64 \%$ of the controls. This suggests that a glutamate receptor with an unusual pharmacological profile is involved. On the basis of the present results, we suggest that this "unusual" receptor includes the $\delta 1 / 2$ subunits that so far have escaped a pharmacological analysis (Wollmuth et al., 2000).

\section{Signaling through AMPA and kainate receptors}

It has been shown in both the nonmammalian and mammalian retina that the light signal from cone bipolar cells onto ganglion cells involves both AMPA and NMDA receptors (Mittman et al., 1990; Diamond and Copenhagen, 1993; Lukasiewicz et al., 1997; Cohen, 2000). The AMPA receptors contribute fast EPSCs, whereas the NMDA receptor-mediated EPSCs have slower rise and decay times. Thus, mainly the temporal characteristics of the signal transfer differs. However, there are also substantial pharmacological differences between NMDA and AMPA receptors such as the voltage dependence, the $\mathrm{Mg}^{2+}$ block, and the $\mathrm{Ca}^{2+}$ permeability of NMDA receptors. Kainate receptors do not appear to be involved in the signal transfer from cone bipolar cells onto ganglion cells (Lukasiewicz et al., 1997). However, because kainate receptors are also present at the cone bipolar cell dyad (Brandstätter et al., 1997; Qin and Pourcho, 2001), they are most likely expressed at the amacrine cell dendrites and not on the ganglion cell dendrites (Shen and Slaughter, 2001). Only one study of the mammalian retina has so far pharmacologically dissected contributions of AMPA and kainate receptors to retinal signaling. DeVries (2000) studied the signal transfer from cones onto off-cone bipolar cells in the ground squirrel and showed that b3 bipolar cells express kainate receptors, whereas b2 and b7 bipolar cells transfer the light signal via AMPA receptors. The result of this pharmacological diversity is a more transient, short latency light response in b2 and b7 bipolar cells and a more sustained, longer latency light response in b3 bipolar cells. If the same difference would also hold for the RB output synapse in the IPL, it would suggest that the signal transfer into AII amacrine cells mediated by AMPA receptor is "fast," whereas the signal transfer to AI cells is "slow." Such a difference in the temporal transfer characteristics would be in agreement with the notion that AII amacrine cells are through conducting neurons, whereas AI cells have a modulatory role (Masland, 1986).

\section{REFERENCES}

Araki K, Meguro H, Kushiya E, Takayama C, Inoue Y, Mishina M (1993) Selective expression of the glutamate receptor channel delta 2 subunit in cerebellar Purkinje cells. Biochem Biophys Res Commun 197:1267-1276.

Baude A, Nusser Z, Roberts JDB, Mulvihill E, McIlhinney RA, Somogyi $\mathrm{P}$ (1993) Glutamate receptor (mGluR1 $\alpha$ ) is concentrated at perisynaptic membrane of neuronal subpopulations as detected by immunogold reaction. Neuron 11:771-787.

Bergersen L, Waerhaug O, Helm J, Thomas M, Laake P, Davies AJ, Wilson MC, Halestrap AP, Ottersen OP (2001) A novel postsynaptic density protein: the monocarboxylate transporter MCT2 is colocalized with delta-glutamate receptors in postsynaptic densities of parallel fiber-Purkinje cell synapses. Exp Brain Res 136:523-534.

Berntson A, Taylor WR (2000) Response characteristics and receptive field widths of on-bipolar cells in the mouse retina. J Physiol (Lond) 524:879-889.

Bloomfield SA, Dacheux RF (2001) Rod vision: pathways and processing in the mammalian retina. Prog Retin Eye Res 20:351-384.

Brandstätter JH, Koulen P, Kuhn R, van der Putten H, Wässle H (1996) Compartmental localization of a metabotropic glutamate receptor (MgluR7): two different active sites at a retinal synapse. J Neurosci 16:4749-4756.

Brandstätter JH, Koulen P, Wässle H (1997) Selective synaptic distribution of kainate receptor subunits in the two plexiform layers of the rat retina. J Neurosci 17:9298-9307.

Brandstätter JH, Koulen P, Wässle H (1998) Diversity of glutamate receptors in the mammalian retina. Vision Res 38:1385-1397.

Brandstätter JH, Fletcher EL, Garner CC, Gundelfinger ED, Wässle H (1999) Differential expression of the presynaptic cytomatrix protein bassoon among ribbon synapses in the mammalian retina. Eur J Neurosci 11:3683-3693.

Burette A, Khatri L, Wyszynski M, Sheng M, Ziff EB, Weinberg RJ (2001) Differential cellular and subcellular localization of AMPA receptor-binding protein and glutamate receptor-interacting protein. J Neurosci 21:495-503.

Cohen ED (2000) Light-evoked excitatory synaptic currents of X-type retinal ganglion cells. J Neurophysiol 83:3217-3229.

Dacheux RF, Raviola E (1986) The rod pathway in the rabbit retina: a depolarizing bipolar and amacrine cell. J Neurosci 6:331-345.

DeVries SH (2000) Bipolar cells use kainate and AMPA receptors to filter visual information into separate channels. Neuron 28:847-856.

Diamond JS, Copenhagen DR (1993) The contribution of NMDA and non-NMDA receptors to the light-evoked input-output characteristics of retinal ganglion cells. Neuron 11:725-738.

Dingledine R, Borges K, Bowie D, Traynelis SF (1999) The glutamate receptor ion channels. Pharmacol Rev 51:7-61. 
Dong H, O'Brien RJ, Fung ET, Lanahan AA, Worley PF, Huganir RL (1997) GRIP: a synaptic PDZ domain-containing protein that interacts with AMPA receptors. Nature 386:279-284.

Dong H, Zhang P, Song I, Petralia RS, Liao D, Huganir RL (1999) Characterization of the glutamate receptor-interacting proteins GRIP1 and GRIP2. J Neurosci 19:6930-6941.

Dowling JE, Boycott BB (1966) Organization of the primate retina: electron microscopy. Proc R Soc Lond B Biol Sci 166:80-111.

Euler T, Masland RH (2000) Light-evoked responses of bipolar cells in a mammalian retina. J Neurophysiol 83:1817-1829.

Euler T, Schneider H, Wässle H (1996) Glutamate responses of bipolar cells in a slice preparation of the rat retina. J Neurosci 16:2934-2944.

Famiglietti EV, Kolb H (1975) A bistratified amacrine cell and synaptic circuitry in the inner plexiform layer of the retina. Brain Res 84:293-300.

Feigenspan A, Teubner B, Willecke K, Weiler R (2001) Expression of neuronal connexin36 in AII amacrine cells of the mammalian retina. J Neurosci 21:230-239.

Fletcher EL, Wässle H (1999) Indoleamine-accumulating amacrine cells are presynaptic to rod bipolar cells through $\mathrm{GABA}_{\mathrm{C}}$ receptors. J Comp Neurol 413:155-167.

Fletcher EL, Hack I, Brandstätter JH, Wässle H (2000) Synaptic localization of NMDA receptor subunits in the rat retina. J Comp Neurol 420:98-112.

Greferath U, Grünert U, Wässle H (1990) Rod bipolar cells in the mammalian retina show protein kinase C-like immunoreactivity. J Comp Neurol 301:433-442.

Grünert U, Martin PR (1991) Rod bipolar cells in the macaque monkey retina: immunoreactivity and connectivity. J Neurosci 11:2742-2758.

Grünert U, Wässle H (1996) Glycine receptors in the rod pathway of the macaque monkey retina. Vis Neurosci 13:101-115.

Grünert U, Martin PR, Wässle H (1994) Immunocytochemical analysis of bipolar cells in the macaque monkey retina. J Comp Neurol 348:607-627.

Hack I, Peichl L, Brandstätter JH (1999) An alternative pathway for rod signals in the rodent retina: rod photoreceptors, cone bipolar cells, and the localization of glutamate receptors. Proc Natl Acad Sci USA 96:14130-14135.

Hartveit E (1999). Reciprocal synaptic interactions between rod bipolar cells and amacrine cells in the rat retina. J Neurophysiol 81:2923-2936.

Hartveit E, Brandstätter JH, Sassoè-Pognetto M, Laurie DJ, Seeburg PH, Wässle H (1994) Localization and developmental expression of the NMDA receptor subunit NR2A in the mammalian retina. J Comp Neurol 348:570-582.

Haverkamp S, Grünert U, Wässle H (2001) The synaptic architecture of AMPA receptors at the cone pedicle of the primate retina. J Neurosci 21:2488-2500

Hollmann M, Heinemann S (1994) Cloned glutamate receptors. Annu Rev Neurosci 17:31-108.

Holmgren-Taylor I (1982) Electron microscopical observations on the indoleamine-accumulating neurons and their synaptic connections in the retina of the cat. J Comp Neurol 208:144-156.

Kennedy MB (2000) Signal-processing machines at the postsynaptic density. Science 290:750-754.

Kohda K, Wang Y, Yuzaki M (2000) Mutation of a glutamate receptor motif reveals its role in gating and $\delta 2$ receptor channel properties. Nat Neurosci 3:315-322

Kolb H, Famiglietti EV (1974) Rod and cone pathways in the inner plexiform layer of the cat retina. Science 186:17-25.

Koulen P, Malitschek B, Kuhn R, Wässle H, Brandstätter JH (1996) Group II and group III metabotropic glutamate receptors in the rat retina: distributions and developmental expression patterns. Eur J Neurosci 8:2177-2187

Koulen P, Fletcher EL, Craven SE, Bredt DS, Wässle H (1998a) Immunocytochemical localization of the postsynaptic density protein PSD-95 in the mammalian retina. J Neurosci 18:10136-10149.

Koulen P, Garner CC, Wässle H (1998b) Immunocytochemical localization of the synapse-associated protein SAP 102 in the rat retina. J Comp Neurol 397:326-336.

Landsend AS, Amiry-Moghaddam M, Matsubara A, Bergersen L, Usami S, Wenthold RJ, Ottersen OP (1997) Differential localization of delta glutamate receptors in the rat cerebellum: coexpression with AMPA receptors in parallel fiber-spike synapses and absence from climbing fiber-spine synapses. J Neurosci 17:834-842.

Lomeli H, Sprengel R, Laurie DJ, Köhr G, Herb A, Seeburg PH, Wisden W (1993) The rat delta-1 and delta-2 subunits extend the excitatory amino acid receptor family. FEBS Lett 315:318-322.

Lukasiewicz PD, Wilson JA, Lawrence JE (1997) AMPA-preferring receptors mediate excitatory synaptic inputs to retinal ganglion cells. J Neurophysiol 77:57-64.

Marc RE, Liu W-LS (2000) Fundamental GABAergic amacrine cell circuitries in the retina: nested feedback, concatenated inhibition, and axosomatic synapses. J Comp Neurol 425:560-582.

Masland RH (1986) The functional architecture of the retina. Sci Am 254:102-111.
Massey SC, Mills SL (1999) Antibody to calretinin stains AII amacrine cells in the rabbit retina: double-label and confocal analyzes. J Comp Neurol 411:3-18.

Menger N, Wässle H (2000) Morphological and physiological properties of the A17 amacrine cell of the rat retina. Vis Neurosci 17:769-780.

Mills SL, Massey SC (1999) AII amacrine cells limit scotopic acuity in central macaque retina: a confocal analysis of calretinin labeling. J Comp Neurol 411:19-34.

Mills SL, Massey SC (2000) A series of biotinylated tracers distinguishes three types of gap junction in the retina. J Neurosci 20:8629-8636.

Mittman S, Taylor WR, Copenhagen DR (1990) Concomitant activation of two types of glutamate receptor mediates excitation of salamander retinal ganglion cells. J Physiol (Lond) 428:175-197.

Muresan V, Lyass A, Schmapp B (1999) The kinesin motor KIF3A is a component of the presynaptic ribbon in vertebrate photoreceptors. J Neurosci 19:1027-1037.

Ozawa S, Kamiya H, Tsuzuki K (1998) Glutamate receptors in the mammalian central nervous system. Prog Neurobiol 54:581-618.

Qin P, Pourcho RG (1999a) AMPA-selective glutamate receptor subunits GluR2 and GluR4 in the cat retina: an immunocytochemical study. Vis Neurosci 16:1105-1114.

Qin P, Pourcho RG (1999b) Localization of AMPA-selective glutamate receptor subunits in the cat retina: a light- and electron-microscopic study. Vis Neurosci 16:169-177.

Qin P, Pourcho RG (2000) Immunocytochemical localization of kainate-selective glutamate receptor subunits in the cat retina. Invest Ophthalmol Vis Sci 41:S246.

Qin P, Pourcho RG (2001) Immunocytochemical localization of kainate-selective glutamate receptor subunits GluR5, GluR6, and GluR7 in the cat retina. Brain Res 890:211-221.

Sandell JH, Masland RH (1986) A system of indoleamine-accumulating neurons in the rabbit retina. J Neurosci 6:3331-3347.

Sandell JH, Masland RH, Raviola E, Dacheux RF (1989) Connections of indoleamine-accumulating cells in the rabbit retina. J Comp Neurol 283:303-313.

Sassoè-Pognetto M, Wässle H, Grünert U (1994) Glycinergic synapses in the rod pathway of the rat retina: cone bipolar cells express the $\alpha 1$ subunit of the glycine receptor. J Neurosci 14:5131-5146.

Scannevin RH, Huganir RL (2000) Postsynaptic organization and regulation of excitatory synapses. Nat Rev Neurosci 1:133-141.

Seeburg PH (1997) A silent channel opens its gates. Nature 388:716-717

Shen W, Slaughter MM (2001) Multireceptor GABAergic regulation of synaptic communication in amphibian retina. J Physiol (Lond) 530:55-67.

Soucy E, Wang YS, Nirenberg S, Nathans J, Meister M (1998) A novel signaling pathway from rod photoreceptors to ganglion cells in mammalian retina. Neuron 21:481-493.

Sterling P, Lampson LA (1986) Molecular specificity of defined types of amacrine synapse in cat retina. J Neurosci 6:1314-1324.

Strettoi E, Raviola E, Dacheux RF (1992) Synaptic connections of the narrow-field bistratified rod amacrine cell (AII) in the rabbit retina. J Comp Neurol 325:152-168.

Tachibana M (1999) Regulation of transmitter release from retinal bipolar cells. Prog Biophys Mol Biol 72:109-133.

tom Dieck S, Sanmarti-Vila L, Langnaese K, Richter K, Kindler S, Soyke A, Wex H, Smalla K-H, Kämpf U, Fränzer J-T, Stumm M, Garner CC, Gundelfinger ED (1998) Bassoon, a novel zinc-finger CAG/glutaminerepeat protein selectively localized at the active zone of presynaptic nerve terminals. J Cell Biol 142:499-509.

Vaney DI (1986) Morphological identification of serotonin-accumulating neurons in the living retina. Science 233:444-446.

Vaney DI, Young HM, Gynther IC (1991) The rod circuit in the rabbit retina. Vis Neurosci 7:141-154.

von Gersdorff H (2001) Synaptic ribbons: versatile signal transducers. Neuron 29:7-10.

von Gersdorff H, Vardi E, Matthews G, Sterling P (1996) Evidence that vesicles on the synaptic ribbon of retinal bipolar neurons can be rapidly released. Neuron 16:1221-1227.

Wässle H, Grünert U, Chun M-H, Boycott BB (1995) The rod pathway of the macaque monkey retina: identification of AII-amacrine cells with antibodies against calretinin. J Comp Neurol 361:537-551.

Wässle H, Koulen P, Brandstätter JH, Fletcher EL, Becker C-M (1998) Glycine and GABA receptors in the mammalian retina. Vision Res 38:1411-1430.

Wollmuth LP, Kuner T, Jatzke C, Seeburg PH, Heintz N, Zuo J (2000) The lurcher mutation identifies $\delta 2$ as an AMPA/kainate receptor-like channel that is potentiated by $\mathrm{Ca}^{2+}$. J Neurosci 20:5973-5980.

Wyszynski M, Kim E, Yang FC, Sheng M (1998) Biochemical and immunocytochemical characterization of GRIP, a putative AMPA receptor anchoring protein, in rat brain. Neuropharmacology 37:1335-1344.

Zhou C, Dacheux RF (2001) Voltage- and ligand gated currents of AII amacrine cells in the rabbit retina. Invest Ophthalmol Vis Sci 42:3625

Zuo J, De Jager PL, Takahashi KA, Jiang W, Linden DJ, Heintz N (1997) Neurodegeneration in Lurcher mice caused by mutation in $\delta 2$ glutamate receptor gene. Nature 388:769-773. 